\title{
Cytotoxicity Is Predicted by Unbound and Not Total Bilirubin Concentration
}

\author{
SEBASTIÁN D. CALLIGARIS, CRISTINA BELLAROSA, PABLO GIRAUDI, RICHARD P. WENNBERG, J. DONALD OSTROW, \\ AND CLAUDIO TIRIBELLI
}

\author{
CSF AREA Science Park and Dept. BBCM [S.D.C., C.B., P.G., C.T.], University of Trieste, 34012c Trieste, Italy; Department of \\ Pediatrics [R.P.W.]; Department of Medicine [J.D.O.], GI/Hepatology Division, University of Washington, Seattle, WA, 98195
}

\begin{abstract}
Although it has been suggested that the unbound, free, $\left(\mathrm{B}_{\mathrm{f}}\right)$ rather than total $\left(\mathrm{B}_{\mathrm{T}}\right)$ bilirubin level correlates with cell toxicity, direct experimental evidence supporting this conclusion is limited. In addition, previous studies never included a direct measurement of $B_{f}$, using newer, accurate methods. To test "the free bilirubin hypothesis", in vitro cytotoxicity was assessed in four cell lines exposed to different $\mathrm{B}_{\mathrm{f}}$ concentrations obtained by varying $\mathrm{B}_{\mathrm{T}} /$ Albumin ratio, using serum albumins with different binding affinities, and/or displacing unconjugated bilirubin (UCB) from albumin with a sulphonamide. $B_{f}$ was assessed by the modified, minimally diluted peroxidase method. Cytotoxicity varied among cell lines but was invariably related to $\mathrm{B}_{\mathrm{f}}$ and not $\mathrm{B}_{\mathrm{T}}$. Light exposure decreased toxicity parallel to a decrease in $B_{f}$. In the absence of albumin, no cytotoxicity was found at $\mathrm{B}_{\mathrm{f}}$ of $150 \mathrm{nM}$ whereas in the presence of albumin a similar $B_{f}$ resulted in a $40 \%$ reduction of viability indicating the importance of total cellular uptake of UCB in eliciting toxic effect. In the presence of albumin-bound UCB, bilirubin-induced cytotoxicity in a given cell line is accurately predicted by $B_{f}$ irrespective of the source and concentration of albumin, or total bilirubin level. (Pediatr Res 62: 576-580, 2007)
\end{abstract}

$\mathrm{P}$ lasma levels of unconjugated bilirubin (UCB) are elevated in almost all newborn infants. In some infants with markedly elevated plasma UCB levels, bilirubin causes neurotoxicity, sometimes resulting in permanent neurologic dysfunction (1). Management guidelines for jaundiced term and near-term infants, published by the American Academy of Pediatrics (AAP), are based on the premise that total serum bilirubin concentration $\left(\mathrm{B}_{\mathrm{T}}\right)$ is the best available predictor of risk for bilirubin-induced neurologic damage (BIND) (2). Clinical evidence has indicated, however, that $\mathrm{B}_{\mathrm{T}}$, beyond a threshold value of $20 \mathrm{mg} / \mathrm{dL}$, is a poor discriminator of individual risk for BIND $(3,4)$. Since over $99.9 \%$ of total plasma UCB $\left(\mathrm{B}_{\mathrm{T}}\right)$ is bound to albumin or apolipoprotein $\mathrm{D}(5)$ and only unbound bilirubin can enter the brain across an intact blood-brain barrier, the level of

Received April 5, 2007; accepted June 12, 2007.

Correspondence: Sebastián D. Calligaris, Ph.D., Centro Studi Fegato (CSF), Bld Q AREA Science Park Campus Basovizza, ss 14 km 163.5, 34012 Trieste, Italy; e-mail: sebastian.calligaris@csf.units.it

Permanent Address (S.D.C.): Laboratorio de Biología Celular y Molecular, Instituto de Histología y Embriología (IHEM), Facultad de Ciencias Médicas, Universidad Nacional de Cuyo-CONICET, Casilla de Correo 56, Centro Universitario, Parque General San Martín, (5500) Mendoza - Argentina.

This study was supported in part by a grant from Telethon (GGP05062). SC and PG are Ph.D. students sponsored by a fellowship from the Ministry of Foreign Affairs, Rome, Italy. unbound "free" bilirubin $\left(\mathrm{B}_{\mathrm{f}}\right)$ should theoretically provide a more accurate indication of the risk of kernicterus.

Published studies of UCB toxicity in cell cultures, conducted with different types of albumin at varied molar ratios of bilirubin/albumin (6-9) reported an increase in cell damage depending on $\mathrm{B}_{\mathrm{T}}$. The hypothesis that cell injury is correlated better with $\mathrm{B}_{\mathrm{f}}$ was first suggested by Nelson et al. (10) in an in vitro study. Moreover, Ostrow et al. (11) reported a meta analysis of in vitro studies that suggested cytotoxicity was better correlated with $\mathrm{B}_{\mathrm{f}}(11)$. This conclusion was however based on $\mathrm{B}_{\mathrm{f}}$ calculations using published binding constants, rather than direct measurement in the culture medium, and was thus limited by unknown variations in binding associated with differences in the composition of the incubation media.

In jaundiced newborns, plasma $B_{f}$ levels at any given $B_{T}$ or $\mathrm{B}_{\mathrm{T}} /$ albumin ratio can vary widely due to varying concentrations of albumin and apolipoprotein D, differences in the binding affinity, and/or the presence of inhibitors of binding (12). $\mathrm{B}_{\mathrm{f}}$, therefore, cannot be accurately predicted from the concentrations of $\mathrm{B}_{\mathrm{T}}$ and albumin in plasma or culture medium, and must be measured directly. A modified, enzymatic peroxidase method has been developed to measure $B_{f}$ in plasma (12) and tissue culture media (13), with minimal dilution of the sample. This is important, since the binding affinity for UCB decreases markedly with increasing albumin concentration $(12,13)$. This assay is based on the observation that, in the presence of peroxidase and peroxide, unbound bilirubin is oxidized to colorless compounds, whereas proteinbound bilirubin is protected from oxidation (14).

The present study, for the first time, directly tests the hypothesis that $B_{f}$, measured with the peroxidase method, rather than $\mathrm{B}_{\mathrm{T}}$ predicts the toxicity of UCB in several cell lines under a wide variety of incubation conditions, using 3(4,5dimethiltiazolil-2)-2,5 diphenyl tetrazolium (MTT) reduction to assess cell viability.

\section{MATERIALS AND METHODS}

Materials. UCB, DMSO (DMSO, HPLC grade), horseradish peroxidase (HRP) (EC.1.11.1.7/P 8125, Type I), hydrogen peroxide $\left(\mathrm{H}_{2} \mathrm{O}_{2}, 30 \% \mathrm{wt} / \mathrm{vol}\right)$, fatty acid free human serum albumin (HSA), and fatty acid free BSA

Abbreviations: HSA, human serum albumin; $\mathbf{B}_{\mathrm{T}}$, total unconjugated bilirubin concentration; $\mathbf{U C B}$, unconjugated bilirubin; $\mathbf{B}_{\mathbf{f}}$, unbound "free" bilirubin concentration 
fraction V (BSA), sulfadimethoxine, Nutrient Mixture F-12 HAM (F-12), Eagle's Minimum Essential Medium (EMEM), 3(4,5-dimethiltiazolil-2)2,5 diphenyl tetrazolium (MTT) and nonessential amino acid solution (MEM), were purchased from Sigma Chemical Co--Aldrich, Milan, Italy. PBS, Dulbecco's modified Eagle's medium-high glucose (DMEMHG), penicillin, and streptomycin were purchased from Euroclone, Milan, Italy. FCS (FCS) and GlutaMAX ${ }^{\mathrm{TM}}$, obtained from Invitrogen (Carlsbad, CA), contained $24 \mathrm{~g} / \mathrm{L}$ albumin. Chloroform, HPLC grade was obtained from Carlo Erba, Milan, Italy.

Cell culture. A human neuroblastoma cell line (SHSY5Y) was grown under 5\% $\mathrm{CO}_{2}$ in F-12/EMEM (1:1) supplemented with penicillin, streptomycin, GlutaMAX ${ }^{\mathrm{TM}}$, MEM and $15 \%$ FCS. HeLa, primary mouse embryo fibroblast (MEF) and Striatal precursor $2 \mathrm{a} 1$ cell lines (15) were grown in DMEMHG with penicillin, streptomycin and $10 \% \mathrm{FCS}$ at $37^{\circ} \mathrm{C}$, except for $2 \mathrm{a} 1$ cells that were incubated at $33^{\circ} \mathrm{C}$ under $5 \% \mathrm{CO}_{2}$. SHSY5Y and Striatal precursor 2a1 cell lines were kindly provided by Dr S. Gustincich (SISSA, Trieste, Italy). MEF were prepared as described by Hertzog (16). The animal protocol was approved by the Animal Care and Use Committee of the University of Trieste.

Preparation of bilirubin/albumin systems. UCB was purified by the method of Ostrow and Mukerjee (17), divided into 200 or $400 \mu \mathrm{g}$ aliquots, and stored at $-20^{\circ} \mathrm{C}$ until used. Just before use, an aliquot was dissolved in 66 or $133 \mu \mathrm{L}$ DMSO, yielding a stock solution containing $5 \mathrm{mM} \mathrm{UCB}$, which was added to the albumin-containing culture medium to attain the desired $\mathrm{B}_{\mathrm{T}}$ with a final DMSO concentration that did not exceed $1 \%$ (vol/vol).

Cell viability by MTT reduction. Cells were plated in 24 multiwell plates, achieving $70-80 \%$ confluence by the following day. The growing medium was then discarded, cells were washed with PBS at $37^{\circ} \mathrm{C}$ and exposed to UCB dissolved in the respective culture medium containing either FCS $15 \%$ (54 $\mu \mathrm{M}$ albumin), $30 \mu \mathrm{M}$ or $60 \mu \mathrm{M}$ HSA, or $30 \mu \mathrm{M}$ BSA. Control cells were incubated in the same medium to which had been added the same volume of DMSO as the added stock UCB solution. After incubation with the UCB, the medium containing UCB was removed and replaced with culture medium containing MTT $0.5 \mathrm{mg} / \mathrm{mL}$ (18). After incubating the cells with MTT for $2 \mathrm{~h}$ at $37^{\circ} \mathrm{C}$, the medium was discarded and MTT formazan crystals dissolved by adding $0.4 \mathrm{~mL}$ isopropanol/ $\mathrm{HCl} 0.04 \mathrm{M}$ and gentle shaking for $2 \mathrm{~h}$ at $37^{\circ} \mathrm{C}$. After centrifugation, absorbance values at $570 \mathrm{~nm}$ were determined in a LD 400C Luminescence Detector, Beckman Coulter, Milan, Italy. Results were expressed as percentage of MTT reduction by cells not exposed to UCB, which was considered as $100 \%$ viability.

$\boldsymbol{B}_{f}$ measurements. The unbound bilirubin $\left(\mathrm{B}_{\mathrm{f}}\right)$ concentrations were determined using a modification of the horseradish peroxidase assay (12) as described by Roca-Burgos et al. (13). The method involves minimal dilution of the sample, minimizing the effect of dilution of the albumin concentration on binding affinity (19).

Effect of different albumin preparations on $B_{f}$ levels and time course of toxicity. The relationship of $\mathrm{B}_{\mathrm{f}}, \mathrm{B}_{\mathrm{T}}$, and different albumin preparations on binding and toxicity were examined by incubating cells in media containing 30 or $60 \mu \mathrm{M}$ HSA, $30 \mu \mathrm{M}$ BSA or 10\% FCS and varying bilirubin/ albumin molar ratios to yield three ranges of $B_{f}$ concentrations $(10-20$, $40-50$, and $80-90 \mathrm{nM}$ ). Cell viability was ascertained following a $2 \mathrm{~h}$ exposure to bilirubin. This time interval was based on a time course curve made for each cell line.

We compared the susceptibility of four cell lines to bilirubin toxicity: HeLa cells (20) and mouse embryo fibroblasts (21), previously used for bilirubin studies in our laboratory, and two neuronal cell lines, SHSY5Y neuroblastoma cells and striatal precursor $2 \mathrm{a} 1$ cells.

Effect of sulfadimethoxine on $\boldsymbol{B}_{f}$ and cell viability. $\mathrm{B}_{\mathrm{f}}$ was measured under the optimal growth conditions (15\% FCS) for SHSY5Y, with or without $250 \mu \mathrm{M}$ sulfadimethoxine, a strong binding competitor for UCB (22). $\mathrm{B}_{\mathrm{T}}$ ranged from 3 to $32 \mu \mathrm{M}$ with total BSA concentration of $54 \mu \mathrm{M}$. Similar $\mathrm{B}_{\mathrm{f}}$ in the presence and absence of sulfadimethoxine were established by using much lower $\mathrm{B}_{\mathrm{T}}$ concentrations in the presence of sulfadimethoxine. Control systems contained $250 \mu \mathrm{M}$ sulfadimethoxine and the same volume of DMSO, but no UCB. Cells were incubated for $2 \mathrm{~h}$ and MTT assay then performed.

Effect of light exposure on $\boldsymbol{B}_{f}$ and toxicity. The effect of light (1000 lux) on $\mathrm{B}_{\mathrm{f}}$ was evaluated using $15 \%$ FCS and $32 \mu \mathrm{M}$ UCB in F12/EMEM medium. The solution flask was placed $10 \mathrm{~cm}$ below a GE polylux XL F36W/840 fluorescent lamp (General Electric Company, UK) for $60 \mathrm{~min}$, and $\mathrm{B}_{\mathrm{f}}$ measured after warming to $37^{\circ} \mathrm{C}$. SHSY5Y cells were then incubated for $2 \mathrm{~h}$ in medium that had or had not been exposed to light and viability was assessed by MTT assay.

Statistical analysis. Results are expressed as mean \pm SD of three experiments for each experimental condition. Statistical analysis was performed by ANOVA with Tukey test, using GraphPad InStat 3 software (San Diego, CA). Differences among the conditions were considered significant at $p<0.05$.

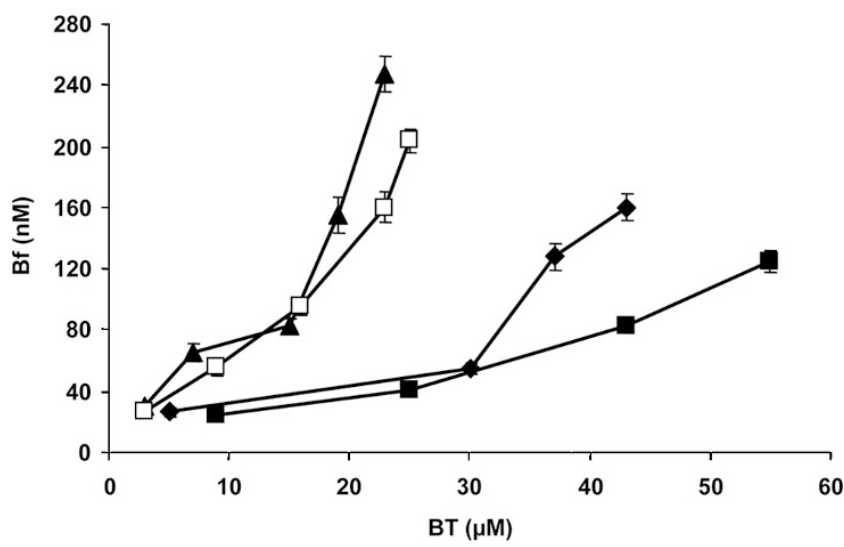

Figure 1. Relationship of $B_{f}$ to $B_{T}$ with four different albumin preparations.

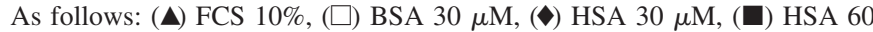
$\mu \mathrm{M}$ Data represent the mean $\pm \mathrm{SD}$ of three independent experiments in triplicate.
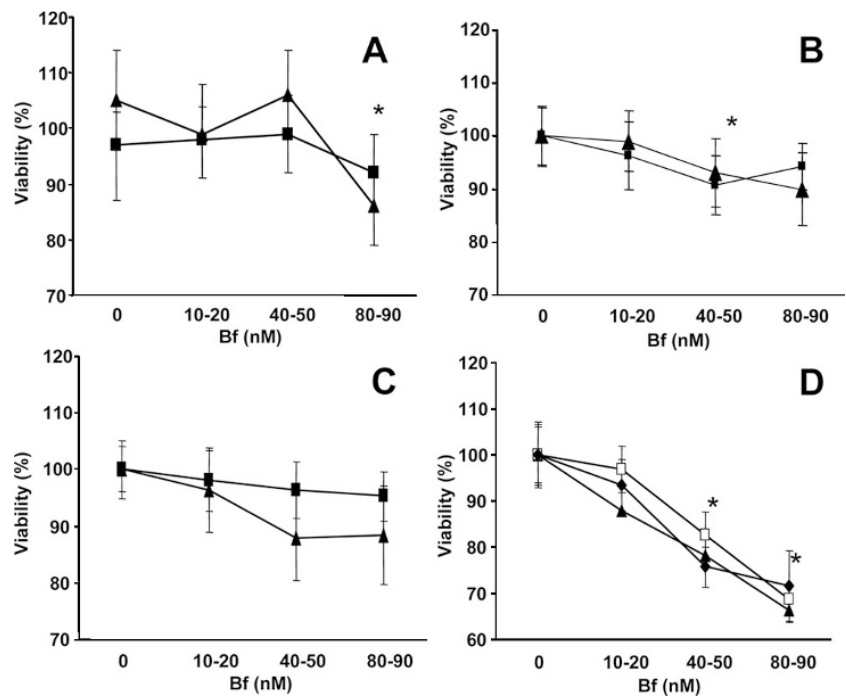

Figure 2. Effect of $B_{f}$ on viability of four different cell lines, assessed by MTT test. 2a1 (A), HeLa (B), MEF(C) were incubated with DMEMHG but SHSY5Y cells (D) were incubated in F12/EMEM medium culture for $2 \mathrm{~h}$ at various $\mathrm{B}_{\mathrm{f}}$ as indicated. HSA $30(\checkmark)$ or $60 \mu \mathrm{M}(\mathbf{\square})$, BSA $30 \mu \mathrm{M}(\square)$ and FCS $10 \%$ ( $\mathbf{\Delta})$ were the bilirubin binders. Data represent the mean \pm SD of three separate experiments in triplicate. $(*) p<0.05$.

\section{RESULTS}

Effect of different binders on $B_{f}$ levels. With all 3 types of albumin, $B_{f}$ increased with increasing $B_{T}$ (Fig. 1). At a given $\mathrm{B}_{\mathrm{T}}, 30 \mu \mathrm{M}$ BSA and $10 \%$ (vol/vol) FCS yielded comparable $B_{f}$ values. These were roughly double the $B_{f}$ obtained using the same concentration of HSA when $\mathrm{B}_{\mathrm{T}}$ was lower than 15 $\mu \mathrm{M}$, consistent with the weaker binding affinity of BSA (13).

Effect of $B_{f}$ on cell viability in different cell lines. Figure 2 shows the changes in cell viability when the 4 cell lines were exposed to a $B_{f}$ of $10-20,40-50$ and $80-90 \mathrm{nM}$ for $2 \mathrm{~h}$. A constant $B_{f}$ with varying $B_{T}$ was obtained by using albumin preparations with different binding characteristics, as shown in Fig. 1. Irrespective of $\mathrm{B}_{\mathrm{T}}$, similar toxicity was observed at similar $\mathrm{B}_{\mathrm{f}}$ obtained by varying the type of albumin and the $\mathrm{UCB} /$ albumin ratios, or displacing UCB with sulfadimethoxine (Fig. 3). 


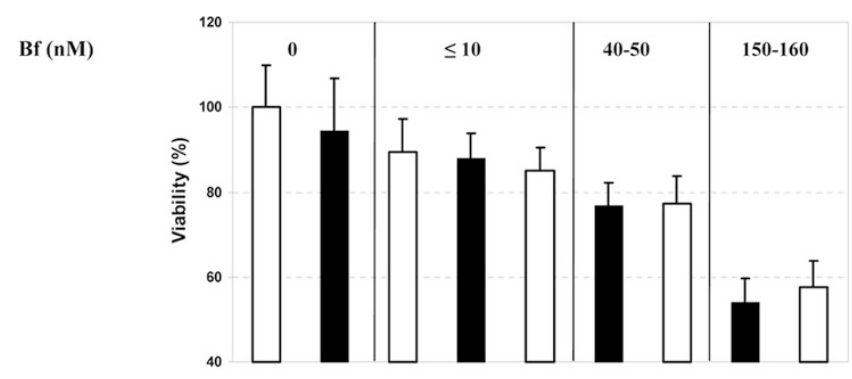

\begin{tabular}{|c|c|c|c|c|c|c|c|c|c|}
\hline $\mathrm{B}_{\mathrm{T}}(\mu \mathrm{M})$ & 0 & 0 & 3 & 3 & 6 & 6 & 12 & 12 & 32 \\
\hline $\begin{array}{c}\text { Molar ratio } \\
\left(\mathrm{B}_{\mathrm{T}} / \mathrm{Albumin}\right)\end{array}$ & 0 & 0 & 0.05 & 0.05 & 0.11 & 0.11 & 0.22 & 0.22 & 0.6 \\
\hline Sulfa $250(\mu \mathrm{M})$ & - & + & - & + & - & + & - & + & - \\
\hline
\end{tabular}

Figure 3. Effect of sulfadimethoxine on $B_{f}$ and cell viability. SHSY5Y cells were incubated in F12/EMEM with 15\% vol/vol FCS (albumin concentration = $54 \mu \mathrm{M}$ ) with (black bars) or without (open bars) $250 \mu \mathrm{M}$ sulfadimethoxine. $\mathrm{B}_{\mathrm{T}}$ was adjusted between 3 to $32 \mu \mathrm{M}$ to yield similar $\mathrm{B}_{\mathrm{f}}$ in the presence and absence of sulfadimethoxine, using much lower $\mathrm{B}_{\mathrm{T}}$ concentrations in the presence of sulfadimethoxine. Control systems contained $250 \mu \mathrm{M}$ sulfadimethoxine but no UCB. Viability was assessed by the MTT assay after $2 \mathrm{~h}$ of incubation with UCB. Data represent the mean \pm SD of three independent experiments performed in triplicate.

Although the susceptibility to damage differed among the 4 cell lines, their viability after two hours of incubation with UCB generally decreased as $B_{f}$ increased (Fig. 2). SHSY5Y cells were most sensitive to UCB with about a $20 \%$ loss of viability at $\mathrm{B}_{\mathrm{f}}=40-50$ and $30 \%$ loss at $\mathrm{B}_{\mathrm{f}}=80-90 \mathrm{nM}(p<$ 0.05 for each). HeLa cells were likewise significantly affected at these concentrations, albeit less severely. In contrast, 2a1 cells showed a modest decrease in viability only at a $\mathrm{B}_{\mathrm{f}}=$ $80-90 \mathrm{nM}(p<0.05)$ while MEF cells showed a trend toward decreased viability that did not achieve statistical significance. Similar results were observed after $1 \mathrm{~h}$ exposure to UCB: viability of SHSY5Y cells was already significantly impaired at $\mathrm{B}_{\mathrm{f}}=40 \mathrm{nM}$, whereas HeLa, 2a1 and MEF cells showed unimpaired survival even at $B_{f}=80-90 \mathrm{nM}$ (data not shown). Longer exposure $(6 \mathrm{~h})$ to a $\mathrm{Bf}=80-90 \mathrm{nM}$ resulted in a further increase in cytotoxicity in SHSY5Y cells $(40 \pm 3 \%$ decrease in viability) and the appearance of a cytotoxic effect in the other cell lines $(20 \pm 5$ for HeLa, $15 \pm 4 \%$ for $2 \mathrm{a} 1$ and $16 \pm 3$ for MEF).

Effect of sulfadimethoxine on $B_{f}$ and on viability of SHSY5Y cells. As shown in Fig. $3, \mathrm{~B}_{\mathrm{f}}$ increased about 5 fold and 3 fold in the presence of sulfadimethoxine, when the bilirubin/FCS molar ratios were 0.11 and 0.22 respectively, confirming the ability of the drug to displace UCB from albumin. Sulfadimethoxine in the absence of UCB had no effect on cell viability $(100 \pm 9.1$ control versus. $94.4 \pm 12.4$ treated cells, NS). Loss of cell viability was comparable at any given $\mathrm{B}_{\mathrm{f}}$ level, irrespective of $\mathrm{B}_{\mathrm{T}}$ (low in the presence of sulfadimethoxine) or $\mathrm{B}_{\mathrm{T}} /$ albumin molar ratio.

Effect of $B_{f}$ on cell viability without albumin. We exposed SHSY5Y cells for $2 \mathrm{~h}$ to $\mathrm{B}_{\mathrm{T}}$ ranging from 10 to $1000 \mathrm{nM}$, without albumin. Thus, all UCB in the medium is initially "free" $\left(\mathrm{B}_{\mathrm{f}}=\mathrm{B}_{\mathrm{T}}\right)$. Cell viability remained unchanged up to $\mathrm{B}_{\mathrm{f}}=500 \mathrm{nM}$ (Fig. 4). In contrast, cells incubated in the presence of $15 \% \mathrm{vol} / \mathrm{vol} \mathrm{FCS}$ and increasing concentrations of

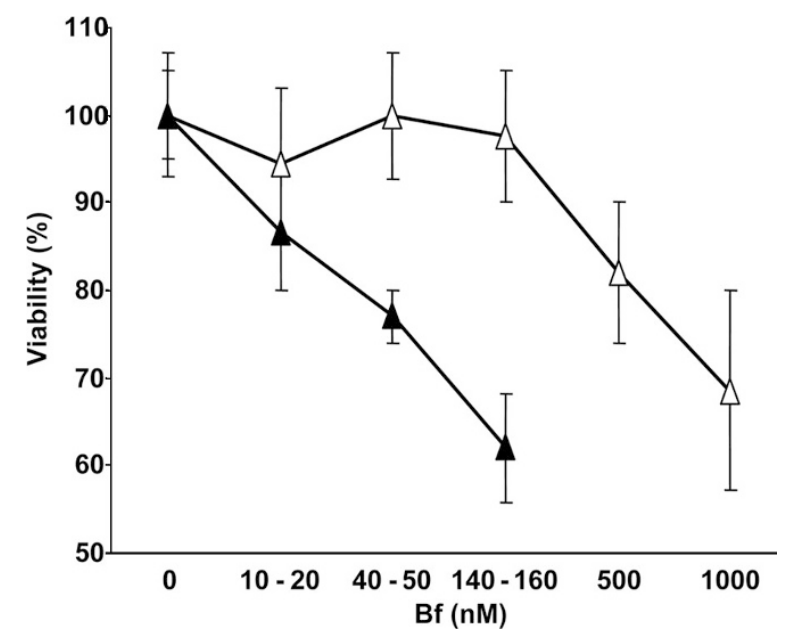

Figure 4. Effect of UCB without albumin on cell viability. SHSY5Y cells were incubated with UCB in F12/EMEM medium without $(\Delta)$ or with $15 \%$ vol/vol FCS $(\boldsymbol{\Delta})$, with $\mathrm{B}_{\mathrm{T}}$ adjusted to yield comparable $\mathrm{B}_{\mathrm{f}}$ in both systems. Viability was assessed by the MTT assay after $2 \mathrm{~h}$ of incubation with UCB. Data represent the mean \pm SD of three separate experiments performed in triplicate.

UCB to achieve $B_{f}$ varying from $10-20$ to $140-160 \mathrm{nM}$ showed cytotoxicity; at a $\mathrm{B}_{\mathrm{f}}$ of $140-150 \mathrm{nM}$, viability was $40-50 \%$ lower $(p<0.001)$.

Effect of light on $B_{f}$ and cell viability. Addition of $32 \pm 1.5$ $\mu \mathrm{M}$ UCB to $15 \%$ FCS (BSA $54 \mu \mathrm{M}$ ) resulted in a $\mathrm{B}_{\mathrm{f}}$ of $164 \pm 16 \mathrm{nM}$ which decreased to $136 \pm 13 \mathrm{nM}$ following 60 min exposure to 1000 lux $(p<0.01)$. $\mathrm{B}_{\mathrm{T}}$ decreased to $27.3 \pm$ $0.9 \mu \mathrm{M}(p<0.01)$ and the calculated apparent binding constant, $\mathrm{K}_{\mathrm{f}}$, (13) assuming one binding site on BSA (23), decreased from $8.98 \pm 0.8 \times 10^{6}$ to $7.44 \times 10^{6} \pm 0.7 \mathrm{M}^{-1}$, $(p<0.06)$. Viability of SHSY5Y cells incubated for $2 \mathrm{~h}$ decreased $45.9 \pm 6.8 \%$ in nonirradiated media, but only $34.6 \pm$ $6.9 \%$ in irradiated media $(p<0.05)$. The improved viability after irradiation was appropriate for the lower $B_{f}$ found. In neither condition did $\mathrm{B}_{\mathrm{f}}$ change significantly during incubation $\left(\mathrm{B}_{\mathrm{f}}=164 \pm 16\right.$ versus. $155 \pm 13$ in non irradiated solution and $136 \pm 14$ versus. $130 \pm 10$ after irradiation). This was anticipated, since uptake of unbound UCB by the cells during incubation was buffered by release of $B_{f}$ from the reservoir of albumin-bound UCB.

\section{DISCUSSION}

In this study we demonstrated variable sensitivity of four different cell lines to bilirubin toxicity. Loss of viability was dependent on the free bilirubin level $\left(\mathrm{B}_{\mathrm{f}}\right)$ but not the total bilirubin concentration $\left(B_{T}\right)$, whether or not the $B_{f}$ is varied by using preparations of albumin with different binding affinities, or by displacement of UCB from albumin by sulfadimethoxine. The results obtained with sulfadimethoxine confirm the observation that viability of cultured 8402 human cells correlated $\left(r^{2}=0.94\right)$ with the square root of $B_{f}$ level, with or without sulfisoxazole (24). SHSY5Y cells, a neuronal model for studies of Alzheimer's disease (25), are more sensitive to UCB cyotoxicity than the 3 nonneuronal cell lines tested. The response of SHSY5Y cells to bilirubin is similar to other neuronal or astrocytic cell lines reported in the literature (11). 
Interestingly, this greater susceptibility of SHSY5Y cells to UCB toxicity is manifested both at lower $B_{f}$ and at shorter incubation times compared with the other three cell lines tested. Although the molecular pathogenesis of bilirubininduced neuronal cell injury is not completely understood, cell damage at any given $B_{f}$ is affected by a variety of mechanisms (26) including export of UCB by ABC transporters, binding of UCB by cytosolic proteins, cellular oxidation and conjugation of UCB.

We observed a marked difference in dose-response when SHSY5Y cells were exposed to UCB in the absence of albumin. The $\mathrm{B}_{\mathrm{f}}$ required for a comparable decrease in viability was more than double that observed with albumin present. Nelson reported similar findings with L929 cells (10). These results can be explained in part by self-aggregation of unbound UCB and by the reservoir function of the albuminbound UCB. The true determinant of UCB cytotoxicity is the intracellular content of UCB. In the absence of the reservoir of albumin-bound UCB, the small amount of unbound UCB in the extracellular fluid in our experimental system $(150 \mathrm{pmol}$ at a $\mathrm{B}_{\mathrm{f}}\left(=\mathrm{B}_{\mathrm{T}}\right)$ of $\left.150 \mathrm{nM}\right)$ is quickly consumed, so that a sufficiently high toxic intracellular level of UCB is not reached. Unfortunately, due to extremely low concentration, it was impossible to measure the "equilibrium" extracellular $\mathrm{B}_{\mathrm{T}}$ in the absence of albumin, or to compare the intracellular UCB concentrations with and without albumin. With albumin present, UCB taken up from the extracellular pool of unbound UCB is instantaneously replaced by dissociation of bound UCB from the albumin, thus maintaining a constant $\mathrm{B}_{\mathrm{f}}$. In the presence of $15 \% \mathrm{FCS}$, a $\mathrm{B}_{\mathrm{f}}$ of $150 \mathrm{nM}$ requires a total bilirubin content of 20,000 pmol i.e., more than 130 times greater than that found at a comparable $\mathrm{Bf}$ in the absence of FCS. Binding to albumin also prevents the pigment from aggregating and precipitating and stabilizes the pigment against oxidation (27). Collectively these data indicate that in addition to the $\mathrm{B}_{\mathrm{f}}$, the total amount of UCB available for uptake is also important to predict cellular damage. In vivo, the presence of a large reservoir of albumin-bound UCB renders this consideration irrelevant.

Application of phototherapy to jaundiced infants produces photo-isomers and photo-oxidative derivatives of UCB. The water soluble photo-isomers are thought to be nontoxic, although confirming experimental evidence is lacking, and they cannot be discriminated from native UCB (bilirubin IX $\alpha_{\mathrm{z}, \mathrm{z}}$ ) by usual assays for $\mathrm{B}_{\mathrm{T}}$. There is evidence that these isomers bind less avidly to albumin (28), and concern has been raised that they will be oxidized faster than bilirubin IX $\alpha_{\mathrm{z}, \mathrm{z}}$, and yield misleading values of $B_{f}(29,30)$. Our data support previous observations that photo-products do not significantly alter the measurement of $\mathrm{B}_{\mathrm{f}}(31,32)$, either by displacing native UCB from the binding site and/or by having a lower binding affinity to the albumin or the peroxidase enzyme. Regardless of mechanism, the predictable relationship between measured $B_{f}$ and toxicity in medium exposed to intense light supports the validity of the peroxidase assay in evaluating risk for bilirubin toxicity when photo-isomers are present.

The presence of serum or albumin in culture media is often necessary for optimal cell growth. The use of BSA or FCS rather than HSA in studies of UCB cytotoxicity in vitro is supported by several reasons among which the most relevant are: 1) BSA is much less expensive than HSA; and 2) BSA has a lower affinity constant for UCB, requiring a much lower $\mathrm{B}_{\mathrm{T}}$ to achieve any given $B_{f}$ level (13). Using the peroxidase method (12), $B_{f}$ can be easily measured without dilution of culture medium in any study where BSA or FCS is used as a $\mathrm{UCB}$ reservoir (13). Measurement of $\mathrm{B}_{\mathrm{f}}$ in all in vitro experiments would greatly facilitate interpretation and comparison of dose-response studies conducted in different laboratories under different conditions.

This study supports the "free bilirubin theory" which hypothesizes that bilirubin toxicity occurs when unbound bilirubin enters the brain and binds to intracellular structures (1). A recent outcome study of newborns exposed to marked hyperbilirubinemia (4) emphasizes the limitation of $\mathrm{B}_{\mathrm{T}}$ as a predictor of neurologic outcome. Verification of $\mathrm{B}_{\mathrm{f}}$ as the critical determinant of toxicity in vitro reinforces the proposal to assess the risk for kernicterus by measuring $B_{f}$ in hyperbilirubinemic newborn plasma (3), rather than depending solely on $\mathrm{B}_{\mathrm{T}}$, as currently recommended by the American Academy of Pediatrics (2).

\section{REFERENCES}

1. Gourley GR 1997 Bilirubin metabolism and kernicterus. Adv Pediatr 44:173-229

2. American Academy of Pediatrics Subcommittee on Hyperbilirubinemia 2004 Management of hyperbilirubinemia in the newborn infant 35 or more weeks of gestation. Pediatrics 114:297-316

3. Wennberg RP, Ahlfors CE, Bhutani VK, Johnson LH, Shapiro SM 2006 Toward understanding kernicterus: a challenge to improve the management of jaundiced newborns. Pediatrics 117:474-485

4. Newman TB, Liljestrand P, Jeremy RJ, Ferriero DM, Wu YW, Hudes ES, Escobar GJ, Jaundice and Infant Feeding Study Team 2006 Outcomes among newborns with total serum bilirubin levels of $25 \mathrm{mg}$ per deciliter or more. N Engl J Med 354:1889-1900

5. Goessling W, Zucker SD 2000 Role of apolipoprotein D in the transport of bilirubin in plasma. Am J Physiol Gastrointest Liver Physiol 279:G356-G365

6. Silva RF, Rodrigues CM, Brites D 2002 Rat cultured neuronal and glial cells respond differently to toxicity of unconjugated bilirubin. Pediatr Res 51:535-541

7. Hanko E, Hansen TW, Almaas R, Paulsen R, Rootwelt T 2006 Synergistic protection of a general caspase inhibitor and MK-801 in bilirubin-induced cell death in human NT2-N neurons. Pediatr Res 59:72-77

8. Keshavan P, Schwemberger SJ, Smith DL, Babcock GF, Zucker SD 2004 Unconjugated bilirubin induces apoptosis in colon cancer cells by triggering mitochondrial depolarization. Int J Cancer 112:433-445

9. Ngai KC, Yeung CY, Leung CS 2000 Difference in susceptibilities of different cell lines to bilirubin damage. J Paediatr Child Health 36:51-55

10. Nelson T, Jacobsen J, Wennberg RP 1974 Effect of $\mathrm{pH}$ on the interaction of bilirubin with albumin and tissue culture cells. Pediatr Res 8:963-967

11. Ostrow JD, Pascolo L, Tiribelli C 2003 Reassessment of the unbound concentrations of unconjugated bilirubin in relation to neurotoxicity in vitro. Pediatr Res 54:98-104

12. Ahlfors CE 2000 Measurement of plasma unbound unconjugated bilirubin. Anal Biochem 279:130-135

13. Roca L, Calligaris S, Wennberg RP, Ahlfors CE, Malik SG, Ostrow JD, Tiribelli C 2006 Factors affecting the binding of bilirubin to serum albumins: validation and application of the peroxidase method. Pediatr Res 60:724-728

14. Jacobsen J, Wennberg RP 1974 Determination of unbound bilirubin in the serum of newborns. Clin Chem 20:783

15. Trettel F, Rigamonti D, Hilditch-Maguire P, Wheeler VC, Sharp AH, Persichetti F, Cattaneo E, McDonald ME 2000 Dominant phenotypes produced by the HD mutation in STHdh(Q111) striatal cells. Hum Mol Genet 9:2799-2809

16. Hertzog PJ 2001 Isolation of embryonic fibroblasts and their use in the in vitro characterization of gene function. Methods Mol Biol 158:205-215

17. Ostrow JD, Mukerjee P 2007 Solvent partition of 14C-unconjugated bilirubin to remove labeled polar contaminants. Transl Res 149:37-45

18. Denizot F, Lang R 1986 Rapid colorimetric assay for cell growth and survival. Modifications to the tetrazolium dye procedure giving improved sensitivity and reliability. J Immunol Methods 89:271-277

19. Ahlfors CE 1981 Effect of serum dilution on apparent unbound bilirubin concentration as measured by the peroxidase method. Clin Chem 27:692-696

20. Calligaris S, Cekic D, Roca-Burgos L, Gerin F, Mazzone G, Ostrow DJ, Tiribelli C 2006 Multidrug resistance associated protein 1 protects against bilirubin-induced cytotoxicity. FEBS Lett 580:1355-1359 
21. Baranano DE, Rao M, Ferris CD, Snyder SH 2002 Biliverdin reductase: a major physiologic cytoprotectant. Proc Natl Acad Sci USA 99:16093-16098

22. Wadsworth SJ, Suh B 1988 In vitro displacement of bilirubin by antibiotics and 2-hydroxybenzoylglycine in newborns. Antimicrob Agents Chemother 32:1571-1575

23. Weisiger RA, Ostrow JD, Koehler RK, Webster CC Mukerjee P, Pascolo L Tiribelli C 2001 Affinity of human serum albumin for bilirubin varies with albumin concentration and buffer composition: results of a novel ultrafiltration method. J Biol Chem 276:29953-29960

24. Pramanik AK, Horn N, Schwemer G 19808402 human cell culture-a model for evaluating bilirubin-albumin interactions with drug. Toxicology 17:255-259

25. Martin H, Lambert MP, Barber K, Hinton S, Klein WL 1995 Alzheimer's-associated phospho-tau epitope in human neuroblastoma cell cultures: up-regulation by fibronectin and laminin. Neuroscience 66:769-779

26. Ostrow JD, Pascolo L, Brites D, Tiribelli C 2004 Molecular basis of bilirubininduced neurotoxicity. Trends Mol Med 10:65-70
27. Ostrow JD, Mukerjee P, Tiribelli C 1994 Structure and binding of unconjugated bilirubin: relevance for physiological and pathophysiological function. J Lipid Res $35: 1715-1737$

28. Lamola AA, Flores J, Blumberg WE 1983 Binding of photobilirubin to human serum albumin. Estimate of the affinity constant. Eur J Biochem 132:165-169

29. McDonagh AF, Maisels MJ 2006 Bilirubin unbound: deja vu all over again? Pediatrics 117:523-525

30. McDonagh AF 2006 Ex uno plures: the concealed complexity of bilirubin species in neonatal blood samples. Pediatrics 118:1185-1187

31. Ahlfors CE, Shwer ML, Wennberg RP 1982 Absence of bilirubin binding competitors during phototherapy for neonatal jaundice. Early Hum Dev 6 : $125-130$

32. Itoh S, Yamakawa T, Onishi S, Isobe K, Manabe M, Sasaki K 1986 The effect of bilirubin photoisomers on unbound-bilirubin concentrations estimated by the peroxidase method. Biochem J 239:417-421 